\title{
An index of floodplain surface complexity
}

\author{
M. W. Scown ${ }^{1}$, M. C. Thoms ${ }^{1}$, and N. R. De Jager ${ }^{2}$ \\ ${ }^{1}$ Riverine Landscapes Research Laboratory, University of New England, Armidale, Australia \\ ${ }^{2}$ Upper Midwest Environmental Sciences Center, United States Geological Survey, La Crosse, Wisconsin, USA
}

Correspondence to: M. W. Scown (mscown2@myune.edu.au)

Received: 26 March 2015 - Published in Hydrol. Earth Syst. Sci. Discuss.: 30 April 2015

Revised: 1 December 2015 - Accepted: 10 December 2015 - Published: 26 January 2016

\begin{abstract}
Floodplain surface topography is an important component of floodplain ecosystems. It is the primary physical template upon which ecosystem processes are acted out, and complexity in this template can contribute to the high biodiversity and productivity of floodplain ecosystems. There has been a limited appreciation of floodplain surface complexity because of the traditional focus on temporal variability in floodplains as well as limitations to quantifying spatial complexity. An index of floodplain surface complexity (FSC) is developed in this paper and applied to eight floodplains from different geographic settings. The index is based on two key indicators of complexity, variability in surface geometry (VSG) and the spatial organisation of surface conditions (SPO), and was determined at three sampling scales. FSC, VSG, and SPO varied between the eight floodplains and these differences depended upon sampling scale. Relationships between these measures of spatial complexity and seven geomorphological and hydrological drivers were investigated. There was a significant decline in all complexity measures with increasing floodplain width, which was explained by either a power, logarithmic, or exponential function. There was an initial rapid decline in surface complexity as floodplain width increased from 1.5 to $5 \mathrm{~km}$, followed by little change in floodplains wider than $10 \mathrm{~km}$. VSG also increased significantly with increasing sediment yield. No significant relationships were determined between any of the four hydrological variables and floodplain surface complexity.
\end{abstract}

\section{Introduction}

The floodplain surface is an important component of floodplain ecosystems. It provides the primary physical template (sensu Southwood, 1977) upon which floodplain ecosystem processes are acted out (Salo, 1990). For example, the floodplain surface provides a succession of geomorphic features upon which vegetation can establish and different communities can develop (Hughes, 1997; Pollock et al., 1998), influencing inundation patterns, soil moisture, and nutrient dynamics (Pinay et al., 2000; De Jager et al., 2012). Topographic complexity of floodplain surfaces contributes to the abundance of different physical habitats (Hamilton et al., 2007), high biodiversity (Ward et al., 1999), and elevated levels of ecosystem productivity (Thoms, 2003), as well as complex nonlinear ecosystem responses to inundation (Murray et al., 2006; Thapa et al., 2015). The majority of floodplain research has focused on temporal variability, in particular how hydrological variability drives floodplain structure and function (Junk et al., 1989; Hughes, 1990; Bayley, 1995; Whited et al., 2007). Such a focus has contributed to a limited appreciation of the spatial complexity of floodplain surfaces.

There are two main components to the spatial complexity of floodplain surfaces (Scown et al., 2015a). The first component relates to the presence/absence, abundance, and diversity of geomorphic features present. This influences the number and range of distinct habitats and potential interactions between those habitats, both of which contribute to complexity (Levin, 1998; Phillips, 2003). The second component is concerned with the spatial organisation of those geomorphic features present within a floodplain surface. Spatial organisation affects local interactions and feedbacks between physical features of any landscape as well as the flux of matter and energy throughout the ecosystems present (Wiens, 2002). 
Any measurement of spatial complexity must incorporate both components, something that does not generally occur (Cadenasso et al., 2006). In addition, riverine landscapes and their floodplains are hierarchically organised ecosystems (Dollar et al., 2007; Thorp et al., 2008), being composed of discrete levels of organisation distinguished by different process rates (O'Neill et al., 1989). Each level of organisation, or holon, has a spatial and temporal scale over which processes occur and patterns emerge (Holling, 1992). Thus, any measurement of spatial complexity must also acknowledge the effects of measurement scale (Scown et al., 2015a).

Studies of floodplain surface complexity have been limited because they tend to only measure one of the components of spatial complexity and often only at a single scale (Scown et al., 2016). Moreover, many of the measures of spatial complexity that have been proposed are based on categorical "patch" data (e.g. Papadimitriou, 2002). Such data have limitations because of the qualitative delineation of patch boundaries, loss of information within patches, and subsequent analyses of these data being restricted to the minimum scale at which patches were initially defined (McGarigal et al., 2009). Continuous numerical data have been used in some studies, and single metrics of surface complexity have been developed, such as rugosity or fractal dimension (see review by Kovalenko et al., 2012). These single-metricbased indices do not fully encompass the multivariate nature of spatial complexity; thus, multiple indicators are required to get the full measure of surface complexity (Dorner et al., 2002; Frost et al., 2005; Tokeshi and Arakaki, 2012). While frameworks encompassing the multiple dimensions of complexity have also been proposed (e.g. Cadenasso et al., 2006), they have not provided a quantitative measure of spatial complexity (Scown et al., 2016).

Environmental conditions that contribute to floodplain surface complexity have remained largely overlooked in floodplain research because of the limited application of quantitative measures of spatial complexity. However, several geomorphological and hydrological drivers are known to influence other floodplain patterns and processes. The valley trough or floodplain width has been identified as a primary controller of floodplain flow and sediment patterns in several previous studies. Spatial patterns of flow depth, velocity, and shear stress in overbank flows were all found by Miller (1995) to be influenced by valley width, and this influence was particularly noticeable at locations of valley widening or narrowing. Similarly, Thoms et al. (2000) found that valley width had a significant effect on sediment texture and associated heavy metal concentrations within different morphological units of the Hawkesbury River valley, New South Wales. The textural character of sediments delivered to the floodplain and local energy conditions during inundation have also been postulated as important controls of floodplain morphology (Nanson and Croke, 1992). In addition to these geomorphological drivers of pattern, hydrological variability is considered a major determinant of floodplain ecosystem processes (Junk et al., 1989; Hughes, 1990; Bayley, 1995; Whited et al., 2007). The influences of environmental drivers on floodplain pattern and process likely extend to floodplain surface complexity; however, determining such relationships requires a quantitative measure of surface complexity.

New technologies are available for intensive data capture, such as light detection and ranging (lidar), and the analysis of these data using geographic information systems (GIS) overcomes many of the limitations that have inhibited the quantification of spatial complexity. Lidar provides highresolution, quantitative topographic data over large areas for many landscapes including floodplains. These data are useful for measuring floodplain surface complexity. Lidar-derived digital elevation models (DEMs) of floodplain surfaces can be used to measure the character and variability of surface features using a suite of surface metrics (McGarigal et al., 2009) and moving window analyses (Bar Massada and Radeloff, 2010; De Jager and Rohweder, 2012). The spatial organisation of these features can then be measured using spatial correlograms and geostatistical models (Rossi et al., 1992). These quantitative measurements of the two components of spatial complexity can be incorporated into a single multivariate index. The advantages of using single indices that can be decomposed into subindices (e.g. for use in assessing ecosystem health; Norris et al., 2007) have been widely favoured in ecosystem research.

A quantitative index of floodplain surface complexity is developed in this study and applied to eight floodplains from different geographic settings. The primary data source is a lidar-derived DEM for each floodplain. The character and variability of surface features and conditions and their spatial organisation are incorporated into a single quantitative index to enable a comparison of surface complexity between floodplains. The different environmental settings of each floodplain provide an opportunity to determine the influence of environmental controls on floodplain surface complexity. In addition, the index is measured over three sampling scales (moving window sizes) to investigate the effects of scale on floodplain surface complexity. In this study we ask two questions: (1) does the surface complexity of the eight floodplains differ and is this consistent among sampling scales? (2) What environmental factors influence floodplain surface complexity?

\section{Study area}

Eight floodplain surfaces from different geographic settings were examined in this study (Fig. 1, Table 1). The Bidgee, Gwydir, Macquarie, Narran, and Yanga floodplains are all located within the Murray-Darling Basin in S.E. Australia, whereas the floodplain of the Woodforde is located in central Australia approximately $150 \mathrm{~km}$ north of the town of Alice Springs. The floodplain of the Shingwedzi is located in N.E. South Africa, in the northern regions of Kruger Na- 
Table 1. Summary of the geographical and climatic settings of the eight study floodplains.

\begin{tabular}{llll}
\hline Floodplain name & Valley setting & Climate & Stream network setting \\
\hline Bidgee & Confined & Semi-arid/temperate & Lowland continuous \\
Gwydir & Unconfined & Semi-arid/temperate & Lowland terminal \\
Macquarie & Unconfined & Semi-arid/temperate & Lowland continuous \\
Mississippi & Confined & Continental & Upland continuous \\
Narran & Unconfined & Semi-arid & Lowland terminal \\
Shingwedzi & Confined & Subtropical & Upland continuous \\
Woodforde & Confined & Arid & Headwaters continuous \\
Yanga & Unconfined & Semi-arid/temperate & Lowland continuous \\
\hline
\end{tabular}

Table 2. Summary of the indicators used to calculate the index of floodplain surface complexity (FSC). Averages and standard deviations of the surface metrics (left columns) are calculated from 50 random sample locations throughout each floodplain. The nugget and range from Moran's I spatial correlograms (right columns) are extracted from the exponential isotropic models fit to these. See Scown et al. (2015a) for detailed calculation procedures.

\begin{tabular}{llll}
\hline \multicolumn{2}{c}{ Indicators of variability in surface geometry } & \multicolumn{1}{c}{ Indicators of spatial organisation of surface conditions } \\
\hline $\begin{array}{l}\text { Average standard deviation } \\
\text { of surface heights }\end{array}$ & $\begin{array}{l}\text { Indicates variability in surface } \\
\text { elevation within an area }\end{array}$ & $\begin{array}{l}\text { Spatial correlogram exponential } \\
\text { isotropic model nugget } \\
(\times 4 \text { metrics })\end{array}$ & $\begin{array}{l}\text { Indicates strength of spatial } \\
\text { organisation }\end{array}$ \\
\hline $\begin{array}{l}\text { Average coefficient of } \\
\text { variation of surface heights }\end{array}$ & $\begin{array}{l}\text { Indicates variability in surface } \\
\text { elevation relative to the mean } \\
\text { elevation within an area }\end{array}$ & $\begin{array}{l}\text { Inverse of the spatial } \\
\text { correlogram exponential } \\
\text { isotropic model range } \\
(\times 4 \text { metrics })\end{array}$ & $\begin{array}{l}\text { Indicates patchiness or } \\
\text { fragmentation in spatial } \\
\text { organisation }\end{array}$ \\
\hline $\begin{array}{l}\text { Standard deviation of } \\
\text { skewness of surface heights }\end{array}$ & $\begin{array}{l}\text { Indicates variability in erosional } \\
\text { and depositional features within } \\
\text { an area }\end{array}$ & & \\
\hline $\begin{array}{l}\text { Average standard deviation } \\
\text { of surface curvature }\end{array}$ & $\begin{array}{l}\text { Indicates how convoluted the } \\
\text { surface is }\end{array}$ & \\
\hline
\end{tabular}

tional Park, and the floodplain of the upper Mississippi is located within navigation pool 9 and forms the boundary of the states of Minnesota, Wisconsin, and Iowa in the USA. Details of the eight floodplains are provided in Table 1 and, in summary, they differ in terms of their degree of valley confinement, climate, and position within the stream network. Four floodplains (the Bidgee, Mississippi, Shingwedzi, and Woodforde) are contained within relatively confined river valley troughs with floodplain widths ranging between 1 and $5 \mathrm{~km}$. The other four floodplains (the Gwydir, Macquarie, Narran, and Yanga) are all contained within relatively unconfined river valleys with floodplain widths of up to $60 \mathrm{~km}$. The eight floodplains also differ in their hydrology and geomorphology, exhibiting a variety of morphological features such as flood channels, oxbows, natural levees, crevasse splays, and back swamps. Detailed descriptions of each of the eight floodplains are provided by Scown et al. (2015a).

\section{Methods}

The index of floodplain surface complexity (FSC) developed for this study was calculated from data extracted from lidarderived DEMs for each floodplain. Floodplain extents were delineated using multiple lines of evidence. This delineation was based on examination of breaks of slope in the DEM, contours, changes in vegetation from aerial photography, soil conditions from local soil conservation surveys, and floodwater extents derived from Landsat TM imagery. A buffer within this manually delineated extent was also removed to ensure nothing other than what was deemed to be part of the floodplain was included. Permanently inundated areas were also removed because attaining accurate subsurface land elevations using lidar is difficult. Each DEM was then detrended to remove the overall downstream slope to ensure it had no effect on topographic measurements. Details of the detrending procedures for each of the floodplains are provided by Scown et al. (2015a, b). Each detrended DEM was subsequently resampled to a $5 \mathrm{~m} \times 5 \mathrm{~m}$ grid size using the cubic 

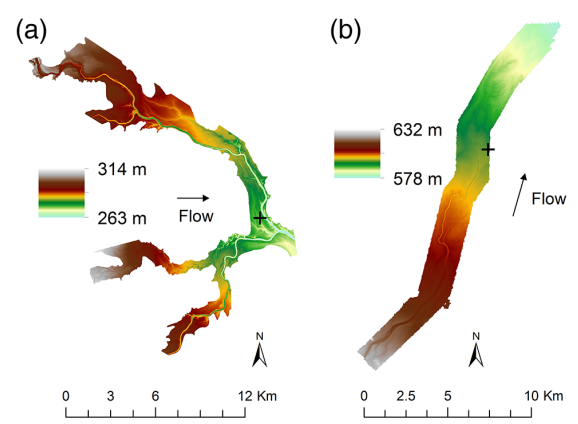

(e)

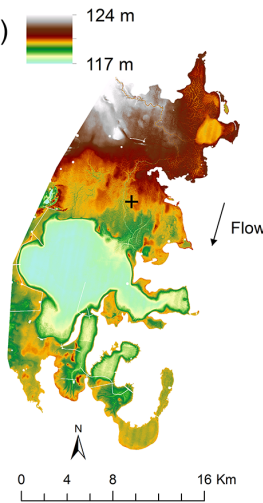

(c)

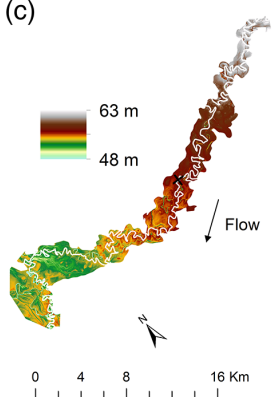

(f)

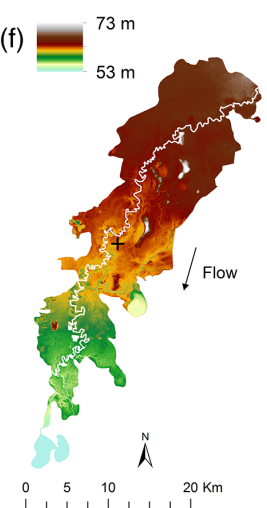

(g)

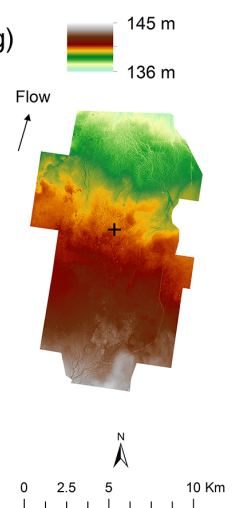

(d)

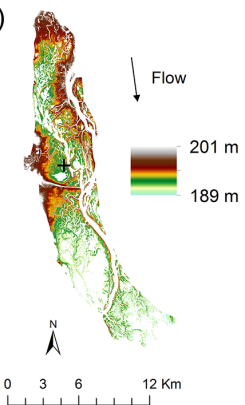

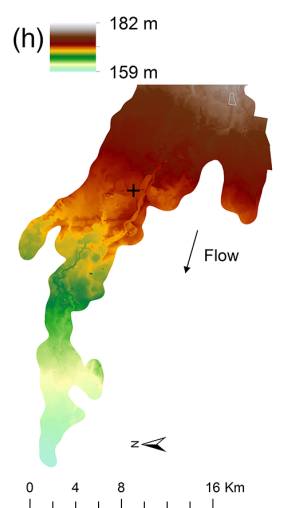

Figure 1. Digital elevation models displaying the floodplain surface in metres above sea level for each study site (crosses indicate coordinates listed): (a) Shingwedzi $\left(31^{\circ} 24^{\prime} \mathrm{E}, 23^{\circ} 05^{\prime} \mathrm{S}\right)$, (b) Woodforde $\left(133^{\circ} 20^{\prime} \mathrm{E}, 22^{\circ} 21^{\prime} \mathrm{S}\right)$, (c) Bidgee $\left(143^{\circ} 24^{\prime} \mathrm{E}, 34^{\circ} 42^{\prime} \mathrm{S}\right)$, (d) Mississippi $\left(91^{\circ} 15^{\prime} \mathrm{W}, 43^{\circ} 29^{\prime} \mathrm{N}\right)$, (e) Narran $\left(147^{\circ} 23^{\prime} \mathrm{E}, 29^{\circ} 48^{\prime} \mathrm{S}\right)$, (f) Yanga (143 $\left.42^{\prime} \mathrm{E}, 34^{\circ} 30^{\prime} \mathrm{S}\right)$, (g) Macquarie $\left(147^{\circ} 33^{\prime} \mathrm{E}, 30^{\circ} 41^{\prime} \mathrm{S}\right)$, and (h) Gwydir $\left(149^{\circ} 20^{\prime} \mathrm{E}, 29^{\circ} 16^{\prime} \mathrm{S}\right)$.

method in ArcGIS 10.2 because this was the finest resolution available for one of the floodplains.

The FSC index is comprised of two subindices, which record the two components of spatial complexity: the variability in surface geometry (VSG) and the spatial organisation of surface conditions (SPO). VSG is a composite of four surface metrics (Table 2), measured at 50 random sample locations throughout each of the floodplains, while SPO is calculated from spatial correlogram models of Moran's I over increasing lag distances for each of the four surface metrics from 1000 random sample locations (Table 2). Details of the procedures for calculating each indicator are provided in Scown et al. (2015a). In summary, the surface metrics are used to indicate increasing surface variability, while the spatial correlogram model parameters (range and nugget) are used to indicate increasing "patchiness" or organisation in the surface (Table 2). It is argued here, and elsewhere (Scown et al., 2015a), that increasing variability and spatial organisation results in increasing spatial complexity. All surface metrics were measured within sampling windows of 50, 200, and $1000 \mathrm{~m}$ radius. These window sizes were chosen based on the identification of scale thresholds between them by Scown et al. (2015b). This enabled us to determine whether any effect of sampling-scale occurred.
The individual indicators were combined and weighted, using the standardised Euclidean distance procedure, to calculate the overall FSC index. This index was used for an overall assessment of floodplain surface complexity and the subindices of VSG and SPO were derived to provide specific interpretations of the two components of spatial complexity for each floodplain surface. An example of FSC calculation is given in Eq. (1), where $\mathrm{I}$ is the overall index and $A, B, C$, $\ldots, N$ are the $n$ individual indicators of surface complexity, the details of which are provided in Table 2.

$I=1-\frac{\sqrt{(1-A)^{2}+(1-B)^{2}+(1-C)^{2}+\ldots+(1-N)^{2}}}{\sqrt{n}}$.

Calculating the FSC index required the SPO indicators to have an additional weighting of 0.5 , as there were twice as many indicators of SPO compared to VSG. All indicators were range-standardised and scaled between 0 and 1 , hence this index provides a relative measure among those floodplains studied. An index value approaching one indicates the floodplain surface is among the most spatially complex of all floodplains observed, while an index value approaching zero indicates the floodplain surface is among the least spatially complex. The approach used has been applied successfully in developing a large-scale index of river condition (Norris et al., 2007). 
Relationships between VSG, SPO, and FSC and seven environmental variables were also investigated. The environmental variables were mean daily discharge (in $\mathrm{ML} \mathrm{day}^{-1}$, $Q)$, the coefficient of variation $(\mathrm{CV})$ of daily discharge $\left(Q_{\mathrm{CV}}\right), \mathrm{CV}$ mean annual discharge $\left(Q_{\mathrm{CVAnn}}\right), \mathrm{CV}$ maximum annual discharge ( $Q_{\text {CVMax }}$ ), sediment yield (in $\mathrm{t} \mathrm{km}^{-2} \mathrm{yr}^{-1}$, $\mathrm{SY}$ ), average valley slope (in $\mathrm{m} \mathrm{m}^{-1}, \mathrm{Vs}$ ), and average floodplain width (in km, Fpw). Detailed calculations of environmental variables are provided by Scown et al. (2015a). Each of these environmental variables reflect an aspect of the flow, sediment, energy, and valley conditions, which have previously been shown to influence floodplain surface morphology (Nanson and Croke, 1992; Warner, 1992). Curve estimation between VSG, SPO, and FSC and each environmental variable at each sampling scale was conducted in SPSS. $Q$, SY, and Vs were normalised using a logarithmic transformation before analysis.

\section{Results}

\subsection{Floodplain surface complexity (FSC)}

Floodplain surface complexity, as measured by the FSC index, was highly variable among the eight floodplains and across sampling scales. The Gwydir floodplain had the least complex of surfaces across all sampling scales (mean FSC of 0.17), while the Shingwedzi floodplain had the most complex surface (mean FSC of 0.69) across all scales (Fig. 2). This presumably reflects differences in the geomorphology of these two floodplains. The Shingwedzi floodplain is dissected by numerous channels and gullies, which create highly organised patches of increased topographic relief, whereas the Gwydir floodplain has a relatively flat, featureless surface over larger continuous areas and limited organisation around any of the significant surface features. The effect of sampling scale on FSC was not consistent across the eight floodplains (Fig. 2), indicating that differences among floodplains are scale-dependent. For example, the Gwydir and Narran floodplain surfaces became more complex with increasing window size, whereas the Shingwedzi, Macquarie, and Mississippi floodplains became less complex.

\subsection{Variability in surface geometry (VSG)}

The VSG index was also highly variable among the eight floodplains and across sampling scales (Fig. 3). Again, the Gwydir floodplain consistently had the lowest values for this index over all window sizes (mean VSG of 0.06), while the Shingwedzi floodplain consistently had the highest (mean VSG of 0.65). This reflects the large differences in topographic relief and variability between these two floodplains. The VSG score of 0.00 for the Gwydir floodplain at the $50 \mathrm{~m}$ window size indicates that this floodplain had the lowest scores for all four indicators of variability in surface ge-

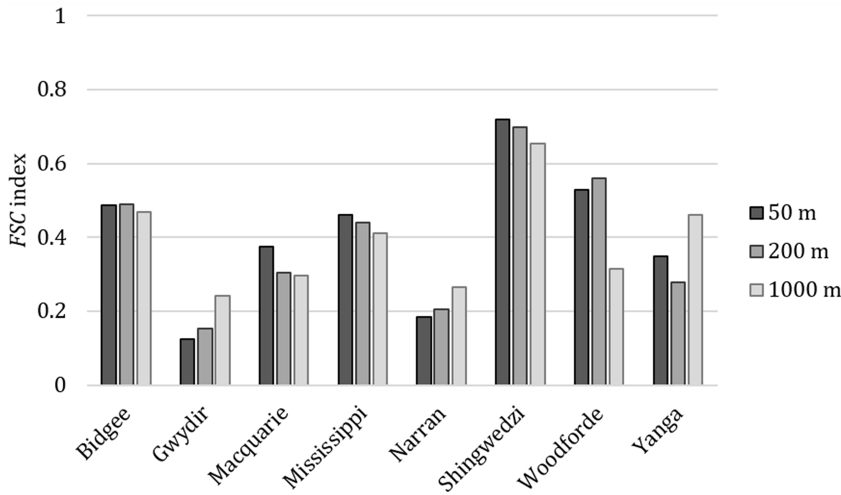

Figure 2. Index of floodplain surface complexity (FSC) for the eight floodplains at each of the three window sizes.

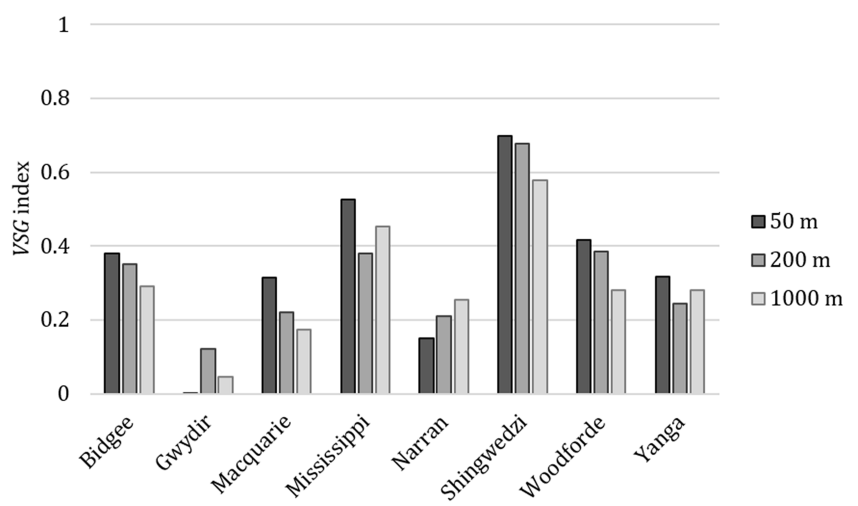

Figure 3. Index of variability in surface geometry (VSG) for the eight floodplains at each of the three window sizes.

ometry of the eight floodplains studied at this scale. Similar to FSC, the effect of sampling scale on VSG was not consistent across floodplains (Fig. 3).VSG increased with sampling scale for the Narran floodplain but decreased for the Shingwedzi, Bidgee, Macquarie, and Woodforde floodplains. VSG was highest at the $50 \mathrm{~m}$ window size and lowest at $200 \mathrm{~m}$ for the Mississippi and Yanga floodplains, while it was highest at $200 \mathrm{~m}$ and lowest at $50 \mathrm{~m}$ for the Gwydir. This indicates that the scale at which surface geometry is most variable depends on the floodplain.

\subsection{Spatial organisation of surface conditions (SPO)}

The SPO index was also highly variable among the eight floodplains and across sampling scales (Fig. 4). Unlike FSC and VSG, there was no consistency as to which floodplain had the highest and lowest SPO across sampling scales. This indicates that no floodplain has consistently the highest or lowest degree of spatial organisation of surface conditions among the eight floodplains studied. The effect of sampling scale on SPO was inconsistent across floodplains (Fig. 4). For five of the eight floodplains, SPO was lowest at the $200 \mathrm{~m}$ window size and highest at $1000 \mathrm{~m}$. For the Mississippi and 


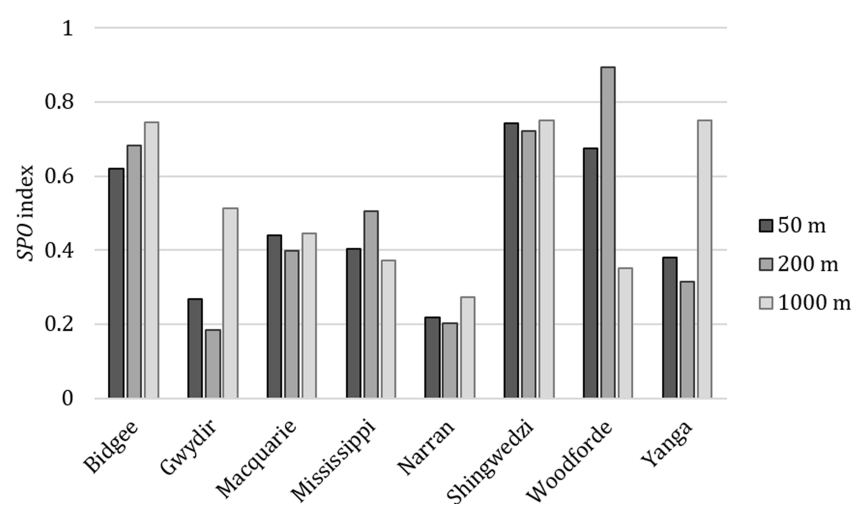

Figure 4. Index of spatial organisation of surface conditions (SPO) for the eight floodplains at each of the three window sizes.

Woodforde floodplains the opposite was observed, with SPO being highest at $200 \mathrm{~m}$ and lowest at $1000 \mathrm{~m}$. The Bidgee floodplain was the only floodplain for which SPO increased consistently across all sampling scales. This indicates that the degree of spatial organisation of surface conditions is highest at large sampling scales for most floodplains, but at intermediate scales for some. SPO was highly variable across window sizes for the Yanga, Woodforde, and Gwydir floodplains. SPO was $178 \%$ higher at the $1000 \mathrm{~m}$ window size than at $200 \mathrm{~m}$ for the Gwydir floodplain and $138 \%$ higher for the Yanga floodplain, while for the Woodforde floodplain it was $61 \%$ lower. This indicates a significant change in the spatial organisation of these floodplain surfaces between these two sampling scales. The results also showed that floodplain and window size have a greater combined effect on SPO among the eight floodplains than on relative FSC and VSG (Figs. 2, 3, 4).

\subsection{Relationships between floodplain surface complexity and environmental variables}

Floodplain width (Fpw) was the only environmental variable statistically related to any of the three indices of spatial complexity $(p<0.05)$. This variable was significantly related to FSC and VSG over all window sizes and to SPO over all but the $1000 \mathrm{~m}$ window size (Table 3). The decrease in all three complexity indices with increasing Fpw was best explained by either a power, logarithmic, or exponential function (Table 3). In terms of the decrease in FSC with increasing Fpw, this was best explained by a power function at all window sizes (Fig. 5a), indicating FSC undergoes rapid decline with increases in Fpw, approaching an asymptote at approximately $10 \mathrm{~km}$ in Fpw. The modelled change in FSC with increasing Fpw was almost identical between the 50 and $200 \mathrm{~m}$ window sizes. At the $1000 \mathrm{~m}$ window size, FSC was generally lower compared to that at 50 and $200 \mathrm{~m}$ windows sizes in narrow floodplains, before approaching a higher asymptote at larger Fpw. This indicates that broad floodplains generally have higher FSC when measured at larger sampling scales, whereas narrow floodplains generally have higher FSC when measured at smaller sampling scales.

Decreases in VSG with increasing Fpw was best explained by a logarithmic function at the $50 \mathrm{~m}$ window size, a power function at the $200 \mathrm{~m}$ window size, and an exponential function at $1000 \mathrm{~m}$ (Fig. 5b). These models indicate a more rapid initial decline in VSG with increasing Fpw at the $200 \mathrm{~m}$ window size than at the 50 and $1000 \mathrm{~m}$ window sizes. This is followed by approach to a higher asymptote at the $200 \mathrm{~m}$ window size above an Fpw of approximately $10 \mathrm{~km}$, whereas modelled VSG continues to decline between Fpw values of 10 and $25 \mathrm{~km}$ at the 50 and $1000 \mathrm{~m}$ window sizes. This indicates that Fpw has a greater effect on VSG in wider floodplains when measured at small and large sampling scales than it does at intermediate scales. The relationship was strongest at the $200 \mathrm{~m}$ window size, with more than $80 \%$ of the variance in VSG being explained by Fpw.

The decrease in SPO with increasing Fpw was best explained by a logarithmic function at the 50 and $200 \mathrm{~m}$ window sizes (Fig. $5 \mathrm{c}$ ). The modelled decline in SPO was initially more rapid at the $50 \mathrm{~m}$ window size than at $200 \mathrm{~m}$, before approaching a higher asymptote at narrower Fpw. This indicates that Fpw has more of an effect on SPO in wider floodplains when measured at the $200 \mathrm{~m}$ window size than at $50 \mathrm{~m}$. The relationship was strongest at the $200 \mathrm{~m}$ window size, with more than $77 \%$ of the variance in SPO being explained by Fpw. This was reduced to $71 \%$ at the $50 \mathrm{~m}$ window size. There was no significant relationship between Fpw and SPO at the $1000 \mathrm{~m}$ window size (Fig. 5c). This suggests that Fpw exerts little or no control over the spatial organisation of surface conditions when measured at large sampling scales.

A weak statistical relationship was recorded between SY and VSG. An increase in VSG with increasing SY was observed at the $200 \mathrm{~m}$ window size $\left(r^{2}=0.44 ; p=0.07\right)$. The relatively lower level of significance of this result was attributable to the Gwydir having a high SY but a very low VSG. When the Gwydir floodplain was removed from the analysis, there was a significant and strong linear relationship between log-transformed SY and VSG across all window sizes for the remaining seven floodplains (Table 4, Fig. 6). This relationship was almost identical across all window sizes.

\section{Discussion}

\subsection{The FSC index}

The Euclidean index of FSC used in this study is comprised of two key components of spatial complexity: the character and variability of features or conditions, and their spatial organisation. This index appears to discriminate between floodplains with distinctly different geomorphological features. 
Table 3. Results from regression analyses of FSC, VSG, and SPO against Fpw at each of the three window sizes. ${ }^{*}$ and italics indicate no significant relationship.

\begin{tabular}{lllllll}
\hline & & Best model & F & d.f. & $p$ & $r^{2}$ \\
\hline \multirow{3}{*}{ FSC } & $50 \mathrm{~m}$ & $y=0.765 x^{-0.414}$ & 10.344 & 1,7 & 0.02 & 0.63 \\
& $200 \mathrm{~m}$ & $y=0.762 x^{-0.420}$ & 25.523 & 1,7 & 0.00 & 0.81 \\
& $1000 \mathrm{~m}$ & $y=0.549 x^{-0.213}$ & 5.871 & 1,7 & 0.05 & 0.50 \\
\hline \multirow{3}{*}{ VSG } & $50 \mathrm{~m}$ & $y=-0.151 \ln x+0.630$ & 9.642 & 1,7 & 0.02 & 0.62 \\
& $200 \mathrm{~m}$ & $y=0.627 x^{-0.418}$ & 26.319 & 1,7 & 0.00 & 0.81 \\
& $1000 \mathrm{~m}$ & $y=0.472 e^{-0.064}$ & 13.574 & 1,7 & 0.01 & 0.69 \\
\hline \multirow{3}{*}{ SPO } & $50 \mathrm{~m}$ & $y=-0.145 \ln x+0.737$ & 14.515 & 1,7 & 0.01 & 0.71 \\
& $200 \mathrm{~m}$ & $y=-0.204 \ln x+0.866$ & 20.586 & 1,7 & 0.00 & 0.77 \\
& $1000 \mathrm{~m}$ & & 0.570 & 1,7 & $0.48^{*}$ & 0.09 \\
\hline
\end{tabular}

Table 4. Results from regression analyses of VSG against each of the three window sizes with Gwydir removed.

\begin{tabular}{llllll}
\hline & Best model & $\mathrm{F}$ & d.f. & $p$ & $r^{2}$ \\
\hline $50 \mathrm{~m}$ & $y=0.183 x+0.088$ & 50.497 & 1,6 & 0.00 & 0.91 \\
$200 \mathrm{~m}$ & $y=0.158 x+0.084$ & 18.179 & 1,6 & 0.00 & 0.78 \\
$1000 \mathrm{~m}$ & $y=0.142 x+0.088$ & 36.076 & 1,6 & 0.00 & 0.88 \\
\hline
\end{tabular}

The multivariate nature of the index, comprised of 12 indicators of surface complexity (Table 2), has advantages over univariate indices that have been applied to measure floodplain surface complexity. Univariate indices fail to incorporate multiple aspects of surface structure that contribute to surface complexity (Dorner et al., 2002; Frost et al., 2005; Tokeshi and Arakaki, 2012). Having a single, multivariatebased index is also favourable, rather than multiple individual indicators of floodplain surface complexity, as it allows for a quantitative measure that can be compared for multiple riverine landscapes. Norris et al. (2007) provide a comparable example of such an application in their assessment of river condition, as do Flotemersch et al. (2015) in their watershed integrity index. It is important to note that, the standardisation of indicator scores from 0 to 1 is necessary for the Euclidean index equation (Norris et al., 2007); as such, the FSC index is a relative index of floodplain surface complexity across a group of floodplains all of which were included in the standardisation of the indicators. This is appropriate for examining relationships between floodplain surface complexity and environmental controls, given adequate replication over a range of floodplain settings is achieved. However, it should not be used to compare against indices of other studies, unless all floodplains being compared are included in the calculation of the index.

Recent approaches to examining and understanding ecosystem complexity and the emergent properties that arise from interactions within systems emphasise the importance of heterogeneity, connectivity, and contingency within the landscape (Loreau et al., 2003; Cadenasso et al., 2006). We have presented an index of floodplain surface complexity within such a framework that incorporates measures of variability and spatial organisation. These two components of spatial complexity are directly associated with heterogeneity and connectivity (Wiens, 2002), although no direct measure of historical contingency is given in this spatial approach. Metrics and indicators used to measure properties of landscape and ecosystem complexity in the past have largely been based on discrete units and the familiar concept of "patches" (Forman and Godron, 1981). The surface metrics employed in this study are conceptually equivalent to certain patch metrics and a comprehensive comparison of surface and patch metrics is provided by McGarigal et al. (2009). Thus, the approach presented in this study should be considered complimentary to other ecosystem complexity frameworks, such as the meta-ecosystem approach (Loreau et al., 2003), which are based on patches.

\subsection{Environmental drivers of floodplain surface complexity}

The results of this research demonstrate that floodplain surface complexity is highly variable among the eight floodplains studied, and that floodplain width exerts a significant top-down control (sensu Thorp et al., 2008) on differences in floodplain surface complexity. These results clearly support geomorphological and ecological thinking that "...the valley rules the stream... ", as argued first by Hynes (1975) and strongly supported since (e.g. Schumm, 1977; Miller, 1995; Panin et al., 1999; Thoms et al., 2000). In this case, the valley rules the floodplain surface complexity, at least in terms of the top-down influences investigated here. The influence of floodplain width on floodplain surface complexity decreases once widths are greater than $10 \mathrm{~km}$. This is likely due to the dissipation of flood energy in wide floodplains, limiting the construction of large topographic features that contribute to surface complexity. However, subtle topographic features in wide floodplains are also importance surface features $(\mathrm{Fa}-$ 

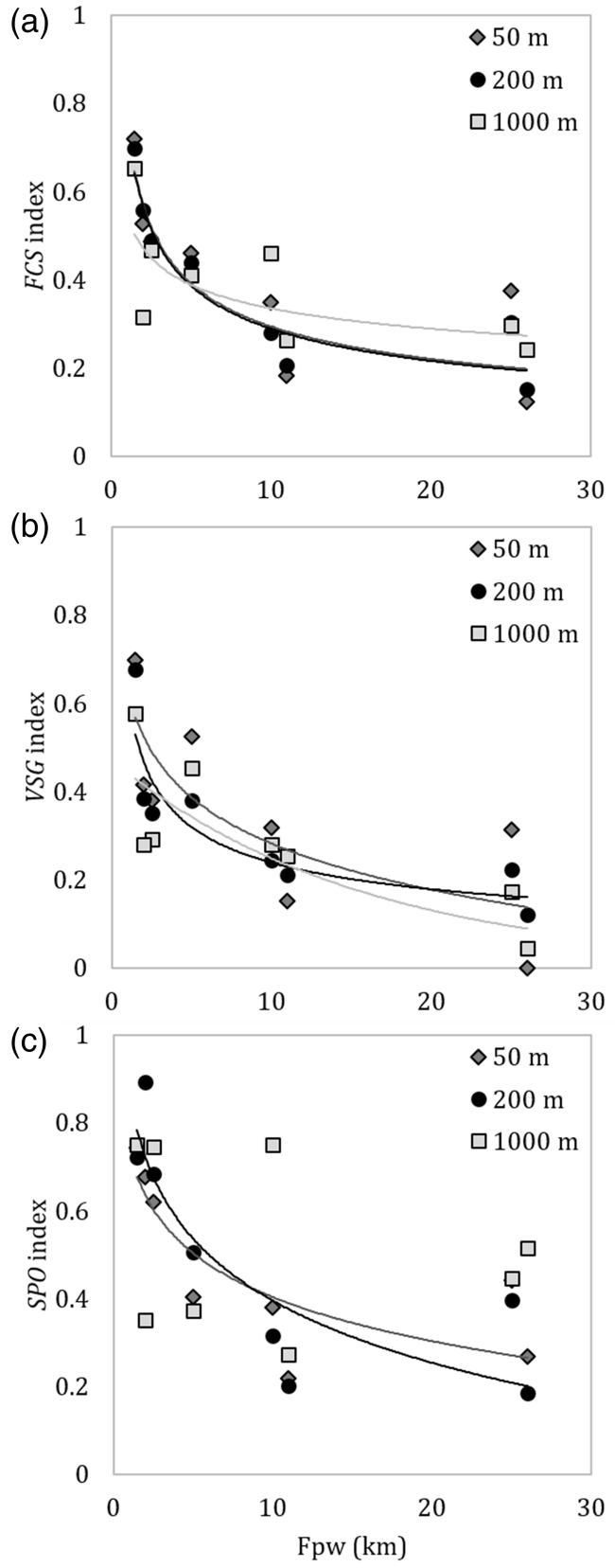

Figure 5. Power relationships between Fpw and (a) FSC, (b) VSG, and (c) SPO at each of the three window sizes.

gan and Nanson, 2004), which may have been overlooked in this index. In narrower, confined settings, where widths are less than $10 \mathrm{~km}$, floodplain construction may be the result primarily of vertical processes (e.g. accretion/incision) leading to more prominent topographic features that exhibit a higher degree of spatial organisation and thus increased surface complexity (Nanson and Croke, 1992). Such complexity can lead to the concentration of flood energies in particular areas, promoting episodic catastrophic stripping (Nanson, 1986). The narrowest floodplain examined in this

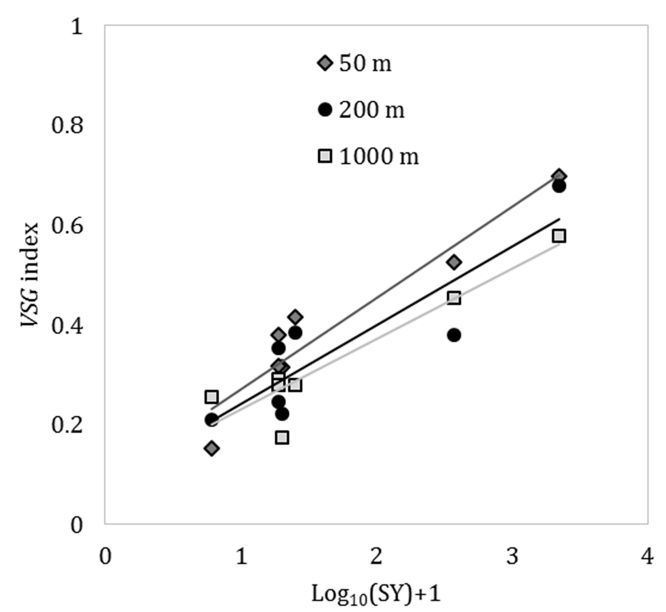

Figure 6. Linear relationships between log-transformed SY and VSG at each of the three window sizes with Gwydir removed.

study was, on average, $1.5 \mathrm{~km}$ in width and the results presented in this study may not apply to narrower floodplains. In particular, there is known to be a loss of surface complexity when floodplains are contained between artificial levees or embankments (Florsheim and Mount, 2002; Gurnell and Petts, 2002), so floodplain surface complexity should not be considered to increase indefinitely with declining width in floodplains.

Contemporary sediment yield estimates were used in this study to investigate the influence of sediment yield on floodplain surface complexity. However, historical sediment yields are thought to be relatively more important in structuring floodplains (Panin et al., 1999). Substantial anthropogenic increases in sediment loads have been reported for the Gwydir floodplain (De Rose et al., 2003), and once this floodplain was removed as an outlier, variability in surface geometry was found to significantly increase with sediment yield. This result suggests that sediment yield may exert top-down control on the variability of floodplain surface geometry, although recent anthropogenic changes in sediment yields (Prosser et al., 2001), particularly increased erosion in the catchment due to land use changes, may have delayed "lag" effects on floodplain surfaces which have not yet been observed (sensu Thoms, 2006).

Valley slope was used in this study as a surrogate for stream energy, and this was not found to have any effect on overall floodplain surface complexity. More accurate measures of energy conditions such as specific stream power (Nanson and Croke, 1992) may reveal effects of energy conditions on floodplain surface complexity. It is also likely that variable flood energy conditions within each floodplain have an effect on localised surface complexity. For example, Fagan and Nanson (2004) found distinct differences in floodplain surface channel patterns among high, intermediate, and low energy areas of the semi-arid Cooper Creek in Australia. 
They also found the energy of flood flows to be largely controlled by floodplain width.

Hydrology has been widely considered the main determinant of floodplain ecosystem patterns and processes (Junk et al., 1989; Hughes, 1990; Bayley, 1995; Whited et al., 2007). However, the research presented in this paper indicates that this may not be the case for floodplain surface complexity. None of the four hydrological variables measured here had a significant effect on floodplain surface complexity. This suggests that, although hydrology is largely important in driving floodplain ecosystem processes, floodplain width and sediment conditions appear to exert more control over the complexity of floodplain surfaces. This is important given that floodplain research and restoration is often focused on hydrology, particularly connectivity (e.g. Thoms, 2003; Thoms et al., 2005), whereas valley trough, sediment, and energy conditions may be more important in structuring and maintaining the physical template upon which hydrology acts as an ecosystem driver (Salo, 1990). Loss of floodplain surface complexity due to changes in sediment yield or calibre, or confinement between artificial levees, may be as ecologically important as changes to hydrology and should not be overlooked (Thoms, 2003). It is important to note, however, that some of the eight floodplains studied have experienced anthropogenic alterations to their hydrology. Thus, hydrological parameters based on contemporary data may not reflect the nature of the flow regime that was influential in establishing current surface conditions; lagged effects of altered hydrology on surface complexity may occur in the future (Thoms, 2006).

In terms of the origin and implications of floodplain surface complexity, this research focuses on top-down environmental drivers (sensu Thorp et al., 2008). Bottom-up feedbacks from the floodplain ecosystem are also likely to affect surface complexity. For example, vegetation establishment on deposited floodplain sediments is known to produce a positive feedback loop in which more sediment is trapped and semi-permanent morphological features such as islands develop (Nanson and Beach, 1977; Hupp and Osterkamp, 1996). Such feedbacks are likely to influence floodplain surface complexity, particularly in floodplains dominated by such features (Gurnell and Petts, 2002; Stanford et al., 2005). Bottom-up influences on floodplain surface complexity are difficult to quantify and were not examined in this study. Future research into the influence of vegetation type and density on floodplain surface complexity, particularly in relation to its hydraulic roughness, may provide valuable insights into bottom-up controls on floodplain surface complexity. Such data are also available through lidar (Straatsma and Baptist, 2008). Effects of floodplain surface complexity on biodiversity and productivity should also be examined in future research. The floodplain surface provides the primary geomorphic template upon which ecosystem processes are acted out (Salo, 1990) and it would be expected that increased surface complexity would promote the range of physical habitats re- quired to maintain floodplain biodiversity (Hamilton et al., 2007).

The inclusion of other floodplains, from different regions, in future studies of this nature would further determine whether the trends observed in this study extend beyond the floodplains investigated here. This study was limited to eight floodplains because of data availability. As high-resolution lidar data across many more floodplains are made available to researchers, other analyses such as multiple regression will be possible in studies such as this. Multiple regression would enable the interactive effects of environmental variables to be elucidated, whereas this study was limited to relatively simple linear regression because of the sample size of only eight floodplains.

\subsection{The effect of scale}

The different sampling scales used in this research indicate that the scale at which patterns in floodplain surfaces are most complex depends on the floodplain setting. In particular, wide, unconfined floodplains appear to have higher floodplain surface complexity when measured at larger sampling scales, whereas narrow, confined floodplains have so at smaller sampling scales. These results suggest that the scales of processes that maximise complexity, and potentially biodiversity and productivity (Tockner and Ward, 1999), in floodplains differ between different valley settings. This has implications for understanding and managing the complexity of floodplain ecosystems. Floodplain processes, which operate over certain temporal scales, elicit a response over relative spatial scales (Salo, 1990; Hughes, 1997). Consequently, managing processes at the appropriate scale to achieve desired outcomes is important (Parsons and Thoms, 2007). This has already been recognised for managing floodplain hydrology to maintain biodiversity (Amoros and Bornette, 2002), and these results indicate it is also important for managing the processes that maintain floodplain surface complexity.

Acknowledgements. The authors wish to thank Janet Hooke and two anonymous reviewers, whose comments on earlier versions greatly improved the manuscript. The authors wish to acknowledge support from the University of New England and the USGS Upper Midwest Environmental Sciences Center, without which this research would not have been possible. Any use of trade, product, or firm names is for descriptive purposes only and does not imply endorsement by the US Government. Data to support this article are available from the authors.

Edited by: T. Kjeldsen

\section{References}

Amoros, C. and Bornette, G.: Connectivity and biocomplexity in waterbodies of riverine floodplains, Freshw. Biol., 47, 761-776, 2002. 
Bar Massada, A. and Radeloff, V. C.: Two multi-scale contextual approaches for mapping spatial pattern, Landsc. Ecol., 25, 711725, 2010

Bayley, P. B.: Understanding large river: floodplain ecosystems, BioScience, 45, 153-158, 1995.

Cadenasso, M. L., Pickett, S. T. A., and Grove, J. M.: Dimensions of ecosystem complexity: heterogeneity, connectivity, and history, Ecol. Complex., 3, 1-12, 2006.

De Jager, N. R. and Rohweder, J. J.: Spatial patterns of aquatic habitat richness in the Upper Mississippi River floodplain, USA, Ecol. Ind., 13, 275-283, 2012.

De Jager, N. R., Thomsen, M., and Yin, Y.: Threshold effects of flood duration on the vegetation and soils of the Upper Mississippi River floodplain, USA, Forest Ecol. Manage., 270, 135146, 2012.

De Rose, R. C., Prosser, I. P., Wiesse, M., and Hughes, A. O.: Patterns of erosion and sediment and nutrient transport in the Murray-Darling Basin, Technical Report 32/03, CSIRO Land and Water, Canberra, Australia, 2003.

Dollar, E. S. J., James, C. S., Rogers, K. H., and Thoms, M. C.: A framework for interdisciplinary understanding of rivers as ecosystems, Geomorphology, 89, 147-162, 2007.

Dorner, B., Lertzman, K., and Fall, J.: Landscape pattern in topographically complex landscapes: issues and techniques for analysis, Landscape Ecology, 17, 729-743, 2002.

Fagan, S. D. and Nanson, G. C.: The morphology and formation of floodplain-surface channels, Cooper Creek, Australia, Geomorphology, 60, 107-126, 2004.

Florsheim, J. L. and Mount, J. F.: Restoration of floodplain topography by sand-splay complex formation in response to intentional levee breaches, Lower Cosumnes River, California, Geomorphology, 44, 67-94, 2002.

Flotemersch, J. E., Leibowitz, S. G., Hill, R. A., Stoddard, J. L., Thoms, M. C., and Tharme, R. E.: A watershed integrity definition and assessment approach to support strategic management of watersheds, River Res. Appl., doi:10.1002/rra.2978, 2015.

Forman, R. T. T. and Godron, M.: Patches and structural components for a landscape ecology, BioScience, 31, 733-740, 1981.

Frost, N. J., Burrows, M. T., Johnson, M. P., Hanley, M. E., and Hawkins, S. J.: Measuring surface complexity in ecological studies, Limnol. Oceanogr.-Meth., 3, 203-210, 2005.

Gurnell, A. M. and Petts, G. E.: Island-dominated landscapes of large floodplain rivers, a European perspective, Freshw. Biol., 47, 581-600, 2002.

Hamilton, S. K., Kellndorfer, J., Lehner, B., and Tobler, M.: Remote sensing of floodplain geomorphology as a surrogate for biodiversity in a tropical river system (Madre de Dios, Peru), Geomorphology, 89, 23-38, 2007.

Holling, C. S.: Cross-scale morphology, geometry, and dynamics of ecosystems, Ecological Monographs, 62, 447-502, 1992.

Hughes, F. M. R.: The influence of flooding regimes on forest distribution and composition in the Tana River floodplain, Kenya, J. Appl. Ecol., 27, 475-491, 1990.

Hughes, F. M. R.: Floodplain biogeomorphology, Prog. Phys. Geogr., 21, 501-529, 1997.

Hupp, C. R. and Osterkamp, W. R.: Riparian vegetation and fluvial geomorphic processes, Geomorphology, 14, 277-295, 1996.

Hynes, H.: The stream and its valley, Verhandlungen des Internationalen Verein Limnologie, 19, 1-15, 1975.
Junk, W. J., Bayley, P. B., and Sparks, R. E.: The flood pulse concept in river-floodplain systems, in Proceedings of the International Large River Symposium, edited by: Dodge, D. P., 110 127, Canadian Special Publication of Fisheries and Aquatic Sciences No. 106, Canadian Government Publishing Centre, Ottawa, Ontario, 1989.

Kovalenko, K., Thomaz, S., and Warfe, D.: Habitat complexity: approaches and future directions, Hydrobiologia, 685, 1-17, 2012.

Levin, S. A.: Ecosystems and the biosphere as complex adaptive systems, Ecosystems, 1, 431-436, 1998.

Loreau, M., Mouquet, N., and Hold, R. D.: Meta-ecosystems: a theoretical framework for a spatial ecosystem ecology, Ecol. Lett., 6, 673-679, 2003.

McGarigal, K., Tagil, S., and Cushman, S.: Surface metrics: an alternative to patch metrics for the quantification of landscape structure, Landsc. Ecol., 24, 433-450, 2009.

Miller, A. J.: Valley morphology and boundary conditions influencing spatial patterns of flood flow, in Natural and Anthropogenic Influences in Fluvial Geomorphology: The Wolman Volume, edited by: Costa, J. E., Miller, A. J., Potter, K. W., and Wilcock, P. R., 57-82, American Geophysical Union, Washington, D. C., 1995.

Murray, O., Thoms, M., and Rayburg, S.: The diversity of inundated areas in semiarid flood plain ecosystems, in Sediment Dynamics and the Hydromorphology of Fluvial Systems, edited by: Rowan, J. S., Duck, R. W., and Werritty, A., 277-286, IAHS Press, Wallingford, UK, 2006.

Nanson, G. C.: Episodes of vertical accretion and catastrophic stripping: a model of disequilibrium flood-plain development, Geol. Soc. Am. Bull., 97, 1467-1475, 1986.

Nanson, G. C. and Beach Forest, H. F.: succession and sedimentation on a meandering-river floodplain, northeast British Columbia, Canada, J. Biogeogr., 4, 229-251, 1977.

Nanson, G. C. and Croke, J. C.: A genetic classification of floodplains, Geomorphology, 4, 459-486, 1992.

Norris, R. H., Linke, S., Prosser, I. P., Young, W. J., Liston, P., Bauer, N., Sloane, N., Dyer, F., and Thoms, M.: Very-broad-scale assessment of human impacts on river condition, Freshw. Biol., 52, 959-976, 2007.

O’Neill, R. V., Johnson, A. R., and King, A. W.: A hierarchical framework for the analysis of scale, Landsc. Ecol., 3, 193-205, 1989.

Panin, A. V., Sidorchuk, A. Y., and Chernov, A. V.: Historical background to floodplain morphology: examples from the East European Plain, in Floodplains: Interdisciplinary Approaches, edited by: Marriott, S. B. and Alexander, J., 217-229, Geological Society Special Publication No. 163, Geological Society, London, UK, 1999.

Papadimitriou, F.: Modelling indicators and indices of landscape complexity: an approach using G.I.S., Ecol. Ind., 2, 17-25, 2002.

Parsons, M. and Thoms, M. C.: Hierarchical patterns of physicalbiological associations in river ecosystems, Geomorphology, 89 , 127-146, 2007.

Phillips, J. D.: Sources of nonlinearity and complexity in geomorphic systems, Prog. Phys. Geogr., 27, 1-23, 2003.

Pinay, G., Black, V. J., Planty-Tabacchi, A. M., Gumiero, B., and Décamps, H.: Geomorphic control of denitrification in large river floodplain soils, Biogeochemistry, 50, 163-182, 2000. 
Pollock, M. M., Naiman, R. J., and Hanley, T. A.: Plant species richness in riparian wetlands - a test of biodiversity theory, Ecology, 79, 94-105, 1998.

Prosser, I. P., Rutherfurd, I. D., Olley, J. M., Young, W. J., Wallbrink, P. J., and Moran, C. J.: Large-scale patterns of erosion and sediment transport in river networks, with examples from Australia, Mar. Freshw. Res., 52, 81-99, 2001.

Rossi, R. E., Mulla, D. J., Journel, A. G., and Eldon, H. F.: Geostatistical tools for modeling and interpreting ecological spatial dependence, Ecol. Monogr., 62, 277-314, 1992.

Salo, J.: External processes influencing origin and maintenance of inland water-land ecotones, in The Ecology and Management of Aquatic-Terrestrial Ecotones, edited by: Naiman, R. J. and Décamps, H., 37-64, Unesco, Paris, France, 1990.

Schumm, S. A.: The Fluvial System, John Wiley and Sons, New York, NY, 338 pp., 1977.

Scown, M. W., Thoms, M. C., and De Jager, N. R.: Floodplain complexity and surface metrics: Influences of scale and geomorphology, Geomorphology, 245, 102-116, 2015a.

Scown, M. W., Thoms, M. C., and De Jager, N. R.: Measuring floodplain spatial patterns using continuous surface metrics at multiple scales, Geomorphology, 245, 87-101, 2015b.

Scown, M. W., Thoms, M. C., and De Jager, N. R.: Measuring spatial pattern in floodplains: a step towards understanding the complexity of floodplain ecosystems, in River Science: Research and Management for the 21st Century, edited by: Greenwood, M. T., Thoms, M. C., and Wood, P. J., John Wiley and Sons, London, UK, 103-131, 2016.

Southwood, T. R. E.: Habitat, the templet for ecological strategies?, J. Animal Ecol., 46, 337-365, 1977.

Stanford, J. A., Lorang, M. S., and Hauer, F. R.: The shifting habitat mosaic of river ecosystems, Verhandlungen des Internationalen Verein Limnologie, 29, 123-136, 2005.

Straatsma, M. W. and Baptist, M. J.: Floodplain roughness parameterization using airborne laser scanning and spectral remote sensing, Remote Sens. Environ., 112, 1062-1080, 2008.
Thapa, R., Thoms, M. C., and Parsons, M.: An adaptive cycle hypothesis of semi-arid floodplain vegetation productivity in dry and wet resource states, Ecohydrology, doi:10.1002/eco.1609, 2015.

Thoms, M. C.: Floodplain-river ecosystems: lateral connections and the implications of human interference, Geomorphology, 56, 335-349, 2003.

Thoms, M. C.: Variability in riverine ecosystems, River Research and Applications, 22, 115-151, 2006.

Thoms, M. C., Parker, C. R., and Simons, M.: The dispersal and storage of trace metals in the Hawkesbury River valley, in River Management: The Australasian Experience, edited by: Brizga, S. and Finlayson, B., 197-219, John Wiley and Sons, Chichester, UK, 2000.

Thoms, M. C., Southwell, M., and McGinness, H. M.: Floodplainriver ecosystems: fragmentation and water resources development, Geomorphology, 71, 126-138, 2005.

Thorp, J. H., Thoms, M. C., and Delong, M. D.: The Riverine Ecosystem Synthesis: Towards Conceptual Cohesiveness in River Science, Elsevier, Amsterdam, 208 pp., 2008.

Tockner, K. and Ward, J. V.: Biodiversity along riparian corridors, Archiv für Hydrobiologie, Supplementband, Large Rivers, 11, 293-310, 1999.

Tokeshi, M. and Arakaki, S.: Habitat complexity in aquatic systems: fractals and beyond, Hydrobiologia, 685, 27-47, 2012.

Ward, J. V., Tockner, K., and Schiemer, F.: Biodiversity of floodplain river ecosystems: ecotones and connectivity, Regulated Rivers: Research \& Management, 15, 125-139, 1999.

Warner, R. F.: Floodplain evolution in a New South Wales coastal valley, Australia: spatial process variations, Geomorphology, 4, 447-458, 1992.

Whited, D. C., Lorang, M. S., Harner, M. J., Hauer, F. R., Kimball, J. S., and Stanford, J. A.: Climate, hydrologic disturbance, and succession: drivers of floodplain pattern, Ecology, 88, 940-953, 2007.

Wiens, J. A.: Riverine landscapes: taking landscape ecology into the water, Freshw. Biol., 47, 501-515, 2002. 